\title{
An Investigation of Elementary School 4-7th Grade Students' Ability to Link Equivalent Fractions' Symbolic and Graphical Representations*
}

\section{Levent ERTUNA**}

\author{
Zülbiye TOLUK UÇAR ${ }^{* * *}$
}

\begin{abstract}
The purpose of this study was to determine elementary school 4-7th grade students' ability to link equivalent fractions' symbolic and graphical representations. The design of this research was a survey study. The sample of the study consisted of 4, 5, 6, and 7th-grade elementary school students in the Sakarya province, Turkey. The study was conducted with 1111 students from 11 elementary schools. Representational Fluency Test (RFT) developed by Niemi (1996) was used as a measurement tool. The RFT included items involving regional areas, line segments, and set representations to assess the part-whole meaning and those involving number lines to assess the measure meaning of the rational number. As the normality assumption was violated, non-parametric tests were applied. The results of the analyses showed that the students' performance to link equivalent fractions' symbolic and graphical representations changed significantly with respect to the representation type (region-line segment, region-number line, set-line segment, set-number line, line segment- number line) and with respect to simple and equivalent fractions. Meanwhile, it was seen that as the classroom levels increased, the success rates in overall scores, representation types, except regionline segment, and simple and equivalent fractions increased.
\end{abstract}

Keywords: Fraction Subconstructs, Equivalence of Fractions, Multiple Representations, Representation of Fractions

\footnotetext{
* This study was produced from the first author's master's thesis, which was conducted under the supervision of the second author.

Ethics committee approval for this study was obtained from the Ethics Committee of Rectorate, Sakarya University, dated 15.09.2021 and numbered 34.

** Orcid ID: https://orcid.org/0000-0001-7810-1168, Dr., Sakarya University, Turkey, leventertuna@sakarya.edu.tr

*** Orcid ID: https://orcid.org/0000-0002-9737-6607, Prof. Dr., Bolu Abant İzzet Baysal University, Turkey, toluk z@ibu.edu.tr
}

Ertuna, L.. \& Toluk Uçar, Z. (2021). An Investigation of Elementary School 4-7th Grade Students' Ability to Link Equivalent Fractions' Symbolic and Graphical Representations. Sakarya University Journal of Education, 11(3), 613631. doi: https://doi.org/10.19126/suje.992377 


\section{INTRODUCTION}

For children, fractions are thought to be one of the more difficult and complicated subjects in elementary school mathematics than most other subjects. A reason for that is that when fractions are handled in real-life problems, they have different interpretations (namely, part-whole, quotient, operator, ratio, and measurement) (Gabriel et al., 2013; Toluk, 2002). Equal division, which can be defined as the essence that each shareholder receives a fair share in the process of division of a whole or a unit into pieces, is one of the most important skills acquired when learning fractions through the part-whole interpretation. However, the fact that it is also the basis for the other interpretations of fractions makes teaching the part-whole interpretation even more important. Due to these characteristics, the part-whole interpretation is the most commonly used interpretation of fractions in the teaching of fractions (Castro-Rodríguez, Pitta-Pantazi, Rico, \& Gómez, 2016; Charalambous \& Pitta-Pantazi, 2007). However, students have difficulty learning these interpretations (especially the measure interpretation of fractions) of rational numbers due to the greater emphasis of the part-whole interpretation and the lack of time allocated to other interpretations in the teaching of fractions (Streefland, 1991). On the other hand, the measure interpretation is linked to number lines and allows students to presume fractions as numbers (Behr, Lesh, Post \& Silver, 1983; Sidney, Thompson, \& Rivera, 2019). With the expression of fractions as numbers and the comprehension of equivalent fractions, the concept of rational numbers emerges, which is one of the goals for teaching fractions.

Equivalent fractions are critical for students to be able to master fractions. This is because equivalent fractions are associated with the ratio and operator interpretations of fractions and thus form the basis for fractional addition, subtraction, and sorting operations (Behr, Khoury, Harel, Post \& Lesh, 1997). Equivalent fractions are a multiplicative relationship referring to the fixed ratio of a numerator and denominator division (Behr, Harel, Post \& Lesh, 1992). Because of this relationship in equivalent fractions, we can deduce that an infinite number of fractions are equal in value. Thus there is an infinite number of fractions that correspond to a point on a number line. However, for elementary school students, equation $1 / 2=2 / 4$ as an equivalent fraction is different from the equations they are used to seeing, such as $1+2=2+1$, which causes confusion (Ni, 2001). Two concepts that underlie the structure of equivalent fractions appear to be at the heart of students' problems with equivalent fractions. The first is the multiplicative relationship, and the second is the property of conservation of the whole and the part (Piaget, 1983, 1987; Piaget, Inhelder \& Szeminska, 1960). A multiplicative relationship is structurally different from step-by-step operations in repetitive additions (as in the sum of $3+3+3+3$ ) where students learn multiplication and involve thinking at two levels at a time that requires considering different situations at the same time (as in $4 \times 3$, for example) (Kamii \& Clark, 1996). In terms of conservation of the whole and part, students ignore the fact that the whole or part will not change even if it is divided into a number of parts. 
Studies on fractions have shown that representations when teaching fractions offer important benefits (Cramer, Wyberg \& Leavitt, 2008; Siebert \& Gaskin, 2006; Cramer \& Henry, 2002; Kieren, 1988). Choosing the appropriate representation among various representations and being aware of the advantages and disadvantages of representations is critical for conceptual understanding in mathematics (Elia, Panaoura, Eracleous, \& Gagatsis, 2007; Even, 1998). Some research (Ainsworth, 2006; Dreher \& Kuntze, 2015; Elia et al., 2007) stated that multiple representations helped students acquire mathematical concepts in a broader and flexible way. Multiple representations play an also crucial role in providing information about the problem and understanding the problem by enabling us to describe and represent mathematics using all possibilities (Choike, 2000; Nistal, Van Dooren, Clarebout, Elen, \& Verschaffel, 2009). Montague (2006) emphasized that students who have difficulties in representation also get in trouble in problem-solving. Moreover, if students are given opportunities to use and practice representational styles, they can identify appropriate representations and convey their ideas while sharing with their peers during the learning process (Lubinski \& Otto, 2002).

\section{Theoretical Framework of the Study}

The theoretical basis for this study is the Lesh Multiple Representations Translations Model, which is used implicitly to represent fractions in mathematics education (Lesh, 1979). The Multiple Representations Translations Model presents five representations types: real-life situations, manipulatives, pictures (static pictures), spoken symbols, and written symbols. This study is based on the representation form of pictures (static pictures) that provides the depiction of mathematical thoughts found in the relevant model since it directly links the mathematical conceptualization (Gravemeijer, Lehrer, van Oers, \& Verschaffel, 2013), and its model is the most preferred in the mathematic education field (Kılıç, 2019; Wong \& Evans, 2011). In this respect, representations were examined in terms of the following representations: regional areas, sets, number lines, and line segments.

The regional area representation is the representation most preferred by teachers. Teachers take it as a basis when they begin teaching fractions, and it expresses the partwhole interpretation of fractions in the most appropriate way. Although the regional area representation appears to be easy at first glance, it can be difficult to learn for some students as it has to be associated with the spatial thinking ability and the concept of regional area (Armstrong \& Larson, 1995). The set representation is a form of representation that contains an equal number of elements in a set and refers to its subsets as fractions. Comprehending this representation may have the same difficulty as, or may be a little more difficult than, the regional area model (Olkun \& Toluk-Uçar, 2004). Students' ability to divide numbers is also crucial in understanding this model. The number line representation gives meaning to the concept of fractions as an abstract real number. Because of this property, the number line representation is the most important representation pointing to the measurement interpretation of fractions (Bright, Behr, Post \& Wachsmuth, 1988; Clarke, Roche, \& Mitchell, 2008; Sidney et al., 
2019). That is why the representation of number lines is more difficult to understand than other representations. Therefore, when teaching fractions, it is more appropriate to teach them at the end, as it will facilitate the teaching process. Apart from the representations of regional areas, sets, and number lines specified in the literature, there is the line segment representation. Although the representation of line segments is considered to be associated with the measurement interpretation of fractions because of its name, as Ni (2001) and Niemi (1996) highlighted, the representation of line segments is related to the part-whole interpretation of fractions. Sample figures about the representations of fractions for $1 / 4$ are shown in Figure 1.

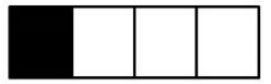

Regional Area representation

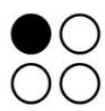

Set representation

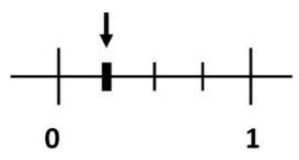

Number Line representation

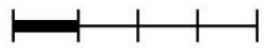

Line Segment representation

Figure 1. The representation for the fractions $1 / 4$

When the relevant literature is reviewed, it becomes clear that some studies examine different interpretations, equivalences, and representations of fractions in separate terms, while others discuss them in groups of two or three. However, studies in which the interpretations of fractions are combined with the representations of fractions in terms of equivalent fractions are almost nonexistent (Ni, 2001; Niemi, 1996; Wong \& Evans, 2011). In their study, Wong and Evans (2011) only used representations of regional areas and sets as representation types. Niemi (1996) used the Representational Fluency Test, which was also used in the present study, and attempted to demonstrate the overall success of fifth-grade students in representing fractions by assessing the results of the test only in the context of representation types. Ni (2001), on the other hand, used the same test to assess fifth and sixth-grade students' representations of equivalent fractions by associating them with different interpretations of fractions. In this regard, the literature's lack of studies on the interpretation, equivalence, and representation of fractions has created a need for further research. Besides, crosssectional examination of students' symbolic and graphical representations of equivalent fractions will aid in the tracking of students' progress on the issue. In this context, the purpose of this study is to identify how well students in grades 4 through 7 can associate symbolic and graphical representations of equivalent fractions. The answers to the following questions were sought.

Does the ability of students in grades 4 through 7 to associate symbolic and graphical representations of equivalent fractions vary depending on:

1. the part-whole and measurement interpretations of rational numbers?

2. grade levels? 
3. the types of graphical representations (regional areas, sets, line segments, and number lines)?

4. whether the representation is a simple or equivalent representation?

\section{METHOD}

\section{Research Design}

This study examines and describes the ability of students to associate symbolic and graphical representations of equivalent fractions, so this was a survey study (Fraenkel, Wallen, \& Hyun, 2019).

\section{Population and Sample}

Ethics committee approval for this study was obtained from the Ethics Committee of Rectorate, Sakarya University, dated 15.09.2021 and numbered 34. The population of the study consisted of students in grades 4 through 7 studying at elementary schools in the Sakarya province, Turkey. Initially, a pilot study was conducted in 3 schools to test the psychometric properties of the measurement instrument. The participants of the actual implementation were selected randomly from 11 schools by using the cluster sampling method. From these selected schools, 1111 students participated in the study in the spring term of 2012. Table 1 presents the distribution of the students participating in the pilot and actual implementation by grade levels and gender.

Table 1

The descriptive statistic of the sample

\begin{tabular}{|c|c|c|c|c|c|c|c|c|c|c|}
\hline \multirow{3}{*}{ Gender } & \multicolumn{8}{|c|}{ Grade Levels } & \multirow{2}{*}{\multicolumn{2}{|c|}{ Total }} \\
\hline & \multicolumn{2}{|c|}{ 4th Grade } & \multicolumn{2}{|c|}{ 5th Grade } & \multicolumn{2}{|c|}{ 6th Grade } & \multicolumn{2}{|c|}{ 7th Grade } & & \\
\hline & Pilot & Actual & Pilot & Actual & Pilot & Actual & Pilot & Actual & Pilot & Actual \\
\hline Female & 43 & 132 & 27 & 134 & 28 & 144 & 39 & 137 & 137 & 547 \\
\hline Male & 39 & 141 & 25 & 150 & 31 & 141 & 25 & 132 & 120 & 564 \\
\hline Total & 82 & 273 & 52 & 284 & 59 & 285 & 64 & 269 & 257 & 1111 \\
\hline
\end{tabular}

Table 1 shows that consisting of 273 (24.6\%) 4th graders, 284 (25.6\%) 5th graders, 285 (25.6\%) 6th graders and 269 (24.2\%) 7th graders, of whom 547 (49.2\%) were female and $564(50.8 \%)$ were male. As a result, it is reasonable to conclude that students at different grade levels are close to each other. 


\section{Instruments}

In this study, the Representational Fluency Test (RFT) developed by Niemi (1996) was administered to describe the ability of students to associate symbolic and graphical representations of equivalent fractions. The original form of the test was prepared to measure the relationship between symbolic and graphical representations of equivalent and non-equivalent fractions. The test uses representations of regional areas, number lines, line segments, and sets to assess fractions' part-whole and measurement interpretations. In the test items, simple and equivalent representations of fractions are graphically represented, and distractors are also given. The test was formed by randomly arranging 18 graphical representations of five different fractional symbols $(1 / 2,2 / 32 / 4,4 / 6$, and 3/2). Thus, RFT includes 90 graphical representations prepared for a total of five fractional symbols. Each fractional symbol also contains wrong fractional representations as distractors. An example item of RTF was presented in Appendix A.

The simple representation of a fraction (also named as a simple fraction by Ni (1999)) is that the graphical representational element (a regional area, a set, a line segment, and a number line) is divided into a number of equal parts specified in the fraction's denominator and represented by specifying as many parts as the numerator. The representation of the representational element by dividing it by the number of multiples or divisors of the number specified in the denominator of a fraction is called the equivalent representation of the fraction (also named as an equivalent fraction by $\mathrm{Ni}$ (1999)). For this reason, the simple and equivalent representations of a fraction differ depending on the numerical value in the numerator and denominator of the fraction $(\mathrm{Ni}$, 2001). For instance, in terms of the symbolic representation of $1 / 2$, the graphical representation constructed by dividing a whole into 2 equal parts and choosing 1 part refers to the simple representation of the fraction, whereas the graphical representation is constructed by dividing the whole into 4 parts and choosing 2 parts or dividing the whole into 6 parts and choosing 3 parts refers to the equivalent representation of the fraction. As another example, in terms of the symbolic representation of $3 / 6$, the graphical representation constructed by dividing a whole into 6 parts and choosing 3 parts refers to the simple representation of the fraction, whereas the graphical representation is constructed by dividing the whole into 4 parts and choosing 2 parts or dividing the whole into 2 parts and choosing 1 part refers to the equivalent representation of the fraction. This situation is explained in Figure 2 by demonstrating the simple and equivalent representations of the fractions $1 / 2$ and $3 / 6$. 
1/2; 3/6;

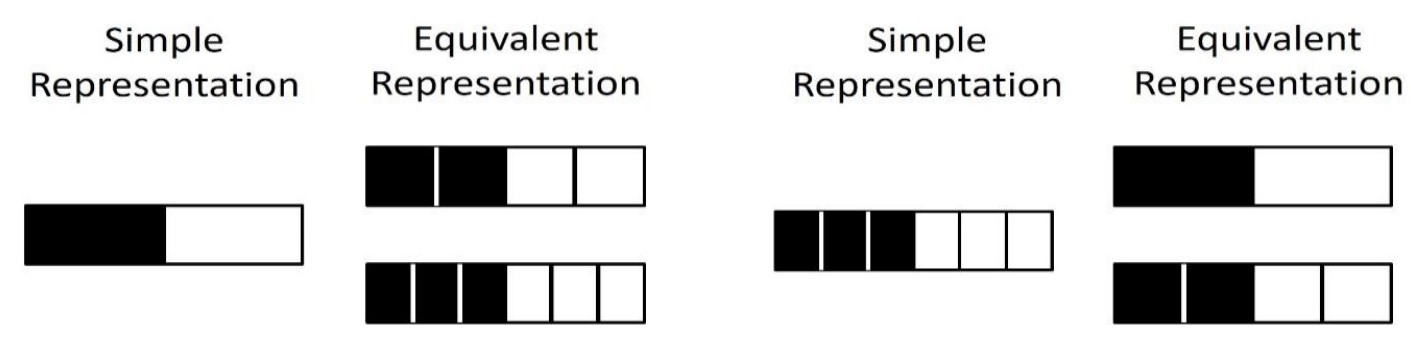

Figure 2. The simple and equivalent representations of the fractions $1 / 2$ and 3/6.

The test was examined to ensure validity by six experts in the respective field. The reliability coefficient was not reported in the studies where the RFT was administered by Niemi (1996) and Ni (2001). In this study, the Kuder Richardson-20 (KR-20) internal consistency coefficient was calculated due to the test's scoring method as the reliability coefficient of the test. In the pilot and final study, the internal consistency coefficient was 0.933 and 0.928 , respectively. These results are considered sufficient for scoring the reliability of the test. Therefore, the RFT was administered in the final study as in the pilot study, without any changes, and the reliability of the test was considered adequate.

\section{Procedure and Data Analysis}

During the scoring of the RFT, for the symbol of each fraction, choosing the representation that was equivalent to the symbol and not selecting the distractors was scored "1," and not selecting the correct representation and selecting distractors were scored "0" each time. The scores were then standardized based on the categories specified in the research questions, with a minimum score of " 0 " and a maximum score of "1."

Before the data analysis, the normality assumptions of the mean comparison test were separately assessed based on the subcategories and grade levels. To this end, the Kolmogorov-Smirnov test was conducted, and graphical outputs and coefficients of skewness and kurtosis were investigated. As the normality assumption was violated, non-parametric tests (the Wilcoxon signed-rank test, the Kruskal-Wallis H test, the Mann-Whitney U test, and the Friedman test) were carried out in accordance with the research questions. Moreover, effect sizes (r) were calculated for situations where there were statistically significant differences between the groups in the study. Cohen (1988) accepts an $r$ value of 0.5 as a large effect size, 0.3 as moderate, and 0.1 as small.

\section{FINDINGS}

This section presents findings and discussions on research questions, respectively. A Wilcoxon signed-ranks test was conducted to examine whether the students' ability to associate symbolic and graphical representations of equivalent fractions differed 
depending on the parts-whole and measurement interpretations of rational numbers (Table 2). As shown in Table 2, the students' mean rank of the part-whole interpretation of rational numbers (620.85) was greater than their mean rank of the measurement interpretation (285.65).

Table 2

Wilcoxon signed-rank test results of the parts-whole and measurement interpretations

\begin{tabular}{lccccc}
\hline Measurement - Parts-Whole & $\mathrm{n}$ & Mean Rank & Sum of Rank & $\mathrm{z}$ & $p$ \\
\hline Negative ranks & 833 & 620.85 & 517170.5 & $-21.562^{*}$ & $.000^{* *}$ \\
Positive ranks & 252 & 285.65 & 71984.5 & & \\
Ties & 26 & & & & \\
\hline
\end{tabular}

* Based on the positive rank

** $p<0.05$

Table 2 shows a significant difference between the mean ranks of the students' scores on the part-whole and measurement interpretations $(\mathrm{z}=-21.562, p<0.05)$. When the mean rank of the difference and the total scores are taken into consideration, it is seen that this observed difference has a moderate effect $(r=0.457)$ in favor of the negative ranks - i.e., the scores on the part-whole interpretation.

As part of the second research question, a Kruskal-Wallis test was carried out to test whether the students' ability to associate symbolic and graphical representations of equivalent fractions differed depending on grade levels (Table 3). Table 3 shows that the mean rank differs from one-grade level to the other, and there is a steady increase in the mean rank scores in the test from grade 4 (470.76) to grade 7 (613.68).

Table 3

Kruskal-Wallis test results of RTF scores according to grade level

\begin{tabular}{lccccccc}
\hline $\begin{array}{l}\text { Grade } \\
\text { Level }\end{array}$ & $\mathrm{n}$ & Mean Rank & $\mathrm{df}$ & $\chi^{2}$ & $p$ & \multicolumn{3}{c}{$\begin{array}{l}\text { Significant } \\
\text { Difference }\end{array}$} \\
\hline $4^{\text {th }}$ Grade & 273 & 470.76 & 3 & 30.920 & $.000^{*}$ & $4^{\text {th }}-5^{\text {th }}, 4^{\text {th }}$ & $-6^{\text {th }}$ \\
$5^{\text {th }}$ Grade & 284 & 550.98 & & & & $4^{\text {th }}-7^{\text {th }}$ & \\
$6^{\text {th }}$ Grade & 285 & 588.21 & & & & & \\
$7^{\text {th }}$ Grade & 269 & 613.68 & & & & & \\
\hline
\end{tabular}

$* p<0.05$ 
Based on the results in Table 3, a statistically significant difference was determined between the students' ability to associate symbolic and graphical representations of equivalent fractions at different grade levels $\left(\chi^{2}{ }_{(3)}=30.920, p<0.05\right)$. Post-hoc test (multiple comparisons) was carried out on pairs of variables to identify which group or groups this difference was in favor of. As indicated in the table, there were differences between grades 4 and 5 (favoring the latter) ( $U=32742.5, r=-0.13$ ), grades 4 and 6 (favoring the latter) ( $\mathrm{U}=31140.5, \mathrm{r}=-0.17$ ) and grades 4 and 7 (favoring the latter) (U $=27234, r=-0.22$ ) based on the analyses. Moreover, 4th graders' ability to associate symbolic and graphical representations of equivalent fractions was concluded to be lower than that of students in other grades.

As part of the third research question, a Friedman test was conducted to test whether the students' ability to associate symbolic and graphical representations of equivalent fractions differed depending on graphical representation types (Table 4). As shown in Table 4, the highest mean rank is 3.34 for the line segment representation, and the lowest mean rank is 1.76 for the number line representation.

Table 4

Friedman test results of RTF scores according to the graphical representations

\begin{tabular}{|c|c|c|c|c|c|c|}
\hline $\begin{array}{l}\text { Types of } \\
\text { Representations }\end{array}$ & $\mathrm{n}$ & $\begin{array}{l}\text { Mean } \\
\text { Rank }\end{array}$ & $\mathrm{df}$ & $\chi^{2}$ & $p$ & Significant Difference \\
\hline Area & 1111 & 2.50 & 3 & 865.636 & $.000^{*}$ & Area-Line S., Area- \\
\hline Set & 1111 & 2.40 & & & & $\begin{array}{l}\text { Number L., } \\
\text { Set- Line S., Set- Number }\end{array}$ \\
\hline Line Segment & 1111 & 3.34 & & & & L., \\
\hline Number Line & 1111 & 1.76 & & & & Line S.- Number L. \\
\hline
\end{tabular}

Based on the results in Table 4, a statistically significant difference was determined between the students' ability to associate symbolic and graphical representations of equivalent fractions depending on graphical representation types $\left(\chi^{2}{ }_{(3)}=865.636, p<\right.$ 0.05). Post-hoc test (multiple comparisons) was carried out on pairs of variables to identify which group or groups this difference was in favor of. As a result of the tests, the difference was found to have a moderate effect between the regional area and line segment representations (favoring the latter) $(\mathrm{z}=-18.542, \mathrm{r}=-0.393)$, between the regional area and number line representations (favoring the former) $(z=-18.456, r=-$ 0.392 ) and between the set and line segment representations (favoring the latter) ( $\mathrm{z}=-$ 15.705, $r=-0.333$ ); a small effect between the set and number line representations (favoring the former) $(\mathrm{z}=-11.095, \mathrm{r}=-0.235)$; and a large effect between the line 
segment and number line representations (favoring the former) $(\mathrm{z}=-25.808, \mathrm{r}=-$ 0.547).

The Wilcoxon signed-rank test was carried out on the data to analyze whether this difference between the scores on simple and equivalent representations of fractions was significant, which is the fifth of the research questions (Table 5). Table 5 indicates that the mean rank of the simple presentation of fractions (598.92) is higher than the mean rank of the equivalent presentation (167.61).

Table 5

Wilcoxon signed-rank test results of the simple and equivalent representations of fractions

\begin{tabular}{lccccc}
\hline $\begin{array}{l}\text { Equivalent Rep.- Simple } \\
\text { Rep. }\end{array}$ & $\mathrm{n}$ & $\begin{array}{l}\text { Mean } \\
\text { Rank }\end{array}$ & Sum of Rank & $\mathrm{z}$ & $p$ \\
\hline Negative ranks & 983 & 598,92 & 588743,00 & $-26.868^{*}$ & $.000^{* *}$ \\
Positive ranks & 120 & 167,61 & 20113,00 & & \\
Ties & 8 & & & & \\
\hline
\end{tabular}

* Based on the positive rank

** $p<0.05$

According to the results in Table 5, it is seen that the scores of the students who participated in the study differed significantly in terms of mean ranks of their scores depending on the simple and equivalent representations of fractions $(\mathrm{z}=-26.868, p<$ 0.05). When the mean rank of the difference and the total scores are taken into consideration, it is seen that this observed difference has a large effect $(r=0.570)$ in favor of the negative ranks - i.e., the scores on the simple presentation of fractions.

\section{DISCUSSION AND SUGGESTIONS}

The findings of the study demonstrated that students were more successful in representing the part-whole interpretation of fractions than the measurement interpretation of fractions, as other studies in the literature have reported (Contreras \& Martinez-Cruz, 2000; Park, Güçler \& McCrory, 2013; Yazgan, 2007). Studies comparing the part-whole and measurement interpretations of equivalent fractions also support the findings of the first research question. According to Larson's (2000) and Ni's (2001) studies, students fail the measurement interpretation of fractions compared to the partwhole interpretation. Similarly, the difference between the part-whole and measurement interpretations could be since the part-whole interpretation is the first one child learns about fractions. On the other hand, another reason for this could be that, as Bright et al. (1988) and Toluk (2002) pointed out, the constant use of the part-whole 
interpretation promotes the belief that fractions are part of a whole rather than referring to a number. It may also be because, as Contreras and Martinez-Cruz (2000), Park et al. (2013) have highlighted, teachers who have been taught predominantly using the part-whole interpretation throughout their education do not spend much time in their classrooms for interpretations other than the part-whole interpretation of fractions.

Students' association of symbolic and graphical representations of fractions was compared in terms of grade levels, and significant differences were found between the grade levels. The current study found that overall achievement scores tended to rise from the fourth to seventh grade, similar to Ni's (2001) findings. The fact that the fourth graders are significantly different from the other grade levels could be since equivalent fractions are taught intensively in the elementary school mathematics curriculum from the fifth grade onwards.

Significant differences in student performance were discovered in the study based on the general representation types. There were two studies in the literature (Ni, 2001; Niemi, 1996) that compared these four types of representations together, while others compared the regional area representation to the number line representation (Contreras \& Martinez-Cruz, 2000; Gürbüz \& Birgin, 2008; Wong \& Evans, 2011). In this context, the studies of $\mathrm{Ni}$ (2001) and Niemi (1996) support the current study's findings. The resulting difference in representations of fractions may be due to that each type of representation has different characteristics. For instance, the reason why the mean score of the regional area representation is greater than the other representations, in general, may be because it is the most used representation by teachers as it supports the part-whole interpretation when introducing fractions (Armstrong \& Larson, 1995; Baykul, 2005; Hull, 2005). However, the fact that the number line representation has the lowest mean score in all research settings can be explained by the fact that the number line representation corresponds to the measurement interpretation, which is difficult to learn, that the number line representation has two separate references points when specifying fractions, and so on (Bright et al., 1988). Moreover, students have problems dividing the whole into equal parts and, accordingly, breaking down points between 0 and 1 either into more or fewer parts than the required parts, which can also be listed as the reasons why students have difficulty representing a number line (Aliustaoğlu, Tuna, \& Biber, 2018; Pesen, 2008; Wong \& Evans, 2011). Another possible reason is that the teachers less support this representation since they have a more conceptual and challenging structure (Putra, 2018; 2019).

There are very few studies in the literature in terms of fractional representations, especially on the representation of line segments, which has the highest mean score in general achievement scores, and the findings - for example, the results of Ni (2001) and Niemi (1996) - are consistent with the findings of this study. Students may try dividing regional areas evenly while dealing with two-dimensional shapes in regional area representations. In contrast, they work with single-dimensional segments in line 
segment representations, which explains why the mean score of the line segment representation is higher than the regional area representation in general scores. Furthermore, the fact that the set representation - with the lowest mean score after the number line representation - differs from the other representations can be explained failure to consider that the objects in the form of a whole that they encounter are actually a set and by their failure to physically divide the objects into pieces (Pesen, 2003). Besides that, the set model requires students to split a given multiplicity into groups of equal size, which necessitates the use of the division operation. Even if the division is correct, the student should be able to think of each group as a unit, regardless of the number of objects in it. To put it another way, the unifying skills of students play a greater role in the use of this representation than others. Lamon (1996) argued that the concept of a flexible unit is crucial to the integration of multiple fractional interpretations.

As Kılıç (2009) and Muzheve (2014) pointed out, another reason for the disparity in the representations of fractions may be the difficulties students have in converting between symbolic and graphical representations. This situation may be due to a lack of support for transformations between representations or sticking to only one representation throughout the teaching process. Moreover, the findings of Toluk-Uçar's (2009) study on preservice teachers support this situation. It can be concluded that teachers project the difficulties they experience in representations and transformations of multiple representations to their students.

The findings from comparing simple and equivalent representations of fractions are consistent with Ni (2001) and Niemi (1996), who compared simple and equivalent fractions. Moreover, the studies of Behr et al. (1983), Hart (1987), Hunting (1984), Kamii and Clark (1995), Wong, Evans, and Anderson (2006), and Wong and Evans (2011) show that students struggle with equivalent fractions, also confirmed the findings of the current study that students were unable to represent equivalent fractions. The reason for this difference emerging in simple and equivalent representations of fractions can be shown to be students' failure to have learned the multiplicative relationship, which is one of the main characteristics that they must have to express equivalent fractions, as Hart (1987) and Kamii and Clark (1995) also pointed out. However, teachers' teaching rules such as "the numerator and denominator of a fraction are multiplied or divided by the same number" rather than teaching the conceptual meaning of equivalent fractions, as Misral (2009) and Ni (2001) stated, may also be the reason why students struggle with equivalent fractions.

In conclusion, students struggle with measurement interpretation, number line representations, and equivalent presentations of fractions. The following recommendations can be made based on all these findings of the study. The use of equal division activities in mathematics teaching can help students perceive fractions, organize them in their minds and learn other relevant topics. In addition, different interpretations of fractions, which are the causes of the difficulties experienced about fractions, should 
be supported in the teaching environment. Furthermore, students' skills and creativity can be improved by using different representations of fractions in operations with fractions, problem-solving, and other similar activities. Moreover, preservice and inservice teachers and students have difficulty in determining how to locate repeating decimals and irrational numbers on the number line (Sirotic \& Zazkis, 2007; Mamolo, 2009; Çaylan Ergene \& Ergene, 2020). In order to overcome these difficulties, a study similar to this research can be designed in repeating decimals.

The current study has some limitations. Although a large sample was reached, this study was conducted with 4 th, 5th, 6th, and 7th-grade students only in a particular region. Secondly, the measurement tool (RTF) contains well-known fractions such as $1 / 2$. That may have provided an advantage to all participants and overestimated their ability. In further studies, the regions that sample various sociodemographic and achievement statuses can be included, and more valid measurement tools can be used to sample equivalent fractions.

\section{References}

Aliustaoğlu, F., Tuna, A., \& Biber, A. C.. (2018). The misconceptions of sixth grade secondary school students on fractions. International Electronic Journal of Elementary Education, 10(5), 591-599.

Armstrong, B., \& Larson, C. (1995). Students' use of part-whole and direct comparison strategies for comparing partitioned rectangles. Journal for Research in Mathematics Education, 26(1), 2-19. doi:10.2307/749225

Baykul, Y. (2005). İlköğretimde matematik öğretimi (1-5.Sınıflar İçin) [Mathematics teaching in primary education (For Grades 1-5)]. Ankara: Pegem Yayıncllık.

Behr, M. J., Harel, G., Post, T. R., \& Lesh, R. (1992). Rational number, ratio, and proportion. In D. A. Grouws (Ed.), Handbook of research on mathematics teaching and learning: A project of the National Council of Teachers of Mathematics (pp. 296-333). Macmillan Publishing Co, Inc.

Behr, M., Khoury, H., Harel, G., Post, T. \& Lesh, R., (1997) Conceptual units analysis of preservice elementary school teachers' strategies on a rational-number-as-operator task. Journal of Mathematics Education, 28(1), 48-69.

Behr, M., Lesh, R., Post, T., \& Silver E. (1983). Rational number concepts. In R. Lesh \& M. Landau (Eds.), Acquisition of Mathematics Concepts and Processes, (pp. 91-125). New York: Academic Press.

Bright, G., Behr, M., Post, T. \& Wachsmuth, I. (1988). Identifying fractions on number lines. Journal for Research in Mathematics Education, 19(3), 215-232. 
Castro-Rodríguez, E., Pitta-Pantazi, D., Rico, L., \& Gómez, P. (2016). Prospective teachers' understanding of the multiplicative part-whole relationship of fraction. Educational Studies in Mathematics, 92(1), 129-146.

Charalambous, C. Y. \& Pitta-Pantazi, D. (2007). Drawing on a theoretical model to study students' understandings of fractions. Educational Studies in Mathematics, 64(3), 293-316.

Clarke, D. M., Roche, A., \& Mitchell, A. (2008). 10 practical tips for making fractions come alive and make sense. Mathematics Teaching in The Middle School, 13(7), 372-380.

Cohen, J. (1988). Statistical power analysis for the behavioral sciences (2nd ed.). Hillsdale, NJ: Lawrence Earlbaum Associates.

Contreras, J. N., Martinez-Cruz, A. M. (2000). Prospective elementary teachers' dominant situations and knowledge about representations of rational numbers. Twenty-second Annual Meeting of the International Group for the Psycology of Mathematics Education, (7-10 October), Tucson, Arizona

Cramer, K. \& Henry, A. (2002). Using manipulative models to build number sense for addition and fractions. In B. Litwiller (Ed.), Making sense of fractions, ratios, and proportions (pp. 41-48). Reston, VA: The National Council of Teachers of Mathematics, Inc.

Cramer, K., Wyberg, T., \& Leavitt, S. (2008). The role of representations in fraction addition and subtraction. Mathematics Teaching in the Middle School. 13(8), 490-496.

Choike, J. (2000). Teaching strategies for algebra for all. The Mathematics Teacher, 93(7), 556-560.

Çaylan-Ergene, B., \& Ergene, Ö. (2020). Repeating decimals and irrational numbers on the number line: Through the lens of pre-service and in-service mathematics teachers. Acta Didactica Napocensia, 13(2), 215-232. https://doi.org/10.24193/adn.13.2.15

Dreher, A., \& Kuntze, S. (2015). Teachers facing the dilemma of multiple representations being aid and obstacle for learning: Evaluations of tasks and theme-specific noticing. Journal für Mathematik-Didaktik, 36(1), 23-44.

Elia, I., Panaoura, A., Eracleous, A., \& Gagatsis, A. (2007). Relations between secondary pupils' conceptions about functions and problem solving in different representations. International Journal of Science and Mathematics Education, 5(3), 533-556.

Even, R. (1998). Factors involved in linking representations of functions. The Journal of Mathematical Behavior, 17(1), 105-121.

Fraenkel, J. R., Wallen, N. E., \& Hyun, H. H. (2019). How to design and evaluate research in education (10th ed.). New York: McGraw-Hill.

Gabriel, F., Coché, F., Szucs, D., Carette, V., Rey, B., \& Content, A. (2013). A componential view of children's difficulties in learning fractions. Frontiers in Psychology, 4, 715. 
Gravemeijer, K. P., Lehrer, R., van Oers, H. J., \& Verschaffel, L. (Eds.). (2013). Symbolizing, modeling and tool use in mathematics education (Vol. 30). Springer Science \& Business Media.

Gürbüz, R. \& Birgin, O. (2008). Farklı öğrenim seviyesindeki öğrencilerin rasyonel sayıların farklı gösterim şekilleriyle işlem yapma performanslarının karşılaştırılması [The comparison of students' performance at different grades regarding to making operation with different types of representation of the rational numbers]. Pamukkale University Journal of Education, 23(1), 85-94.

Hart, K.M. (1987). Practical work and formalisation, too great a gap. J.C. Bergeron, N. Herscovics, C. Kieran. Proceedings of the Eleventh International Conference Psychology of Mathematics Education (PME-XI) Vol II, 408-415. Montreal.

Hull, L. (2005). Fraction models that promote understanding for elementary students. [Unpublished master's thesis]. University of Central Florida.

Hunting, R. P. (1984). Understanding equivalent fractions. Journal of Science and Mathematics Education in Southeast Asia, 7, 26-33.

Kamii, C., \& Clark, F. B. (1995). Equivalent fractions: Their difficulty and educational implications. Journal of Mathematical Behavior, 14, 365-378.

Kılıç, Ç. (2009). İlköğretim beşinci sınıf öğrencilerinin matematiksel problemlerin çözümlerinde kullandıkları temsiller [Representations the Fifth Grade Primary School Students Used in The Process of Solving Mathematical Problems]. (Doctoral Dissertation). Retrieved from Turkish Council of Higher Education Thesis Database (Thesis Number: 235250).

Kieren, T. E. (1988). Personal knowledge of rational numbers: Its intuitive and formal development. In M. J. Behr \& J. Hiebert (Eds), Number concepts and operations in the middle grades (pp. 162-181). Reston, VA: National Council of Teachers of Mathematics.

Larson, N. C. (2000). The development of the part-whole and measure subconstructs of four sixth-graders during an instructional unit. Twenty-second Annual Meeting of the International Group for the Psycology of Mathematics Education, (7-10 October), Tucson, Arizona.

Lesh, R. (1979). Mathematical learning disabilities: Considerations for identification, diagnosis, and remediation. In R. Lesh, D. Mierkiewicz, \& M. G. Kantowski (Eds.), Applied mathematical problem solving (pp. 111-180). Columbus, OH: ERIC/SM.

Lubinski, C. A., \& Otto, A. D. (2002). Meaningful mathematical representations and early algebraic reasoning. Teaching Children Mathematics, 9(2), 76-80.

Mamolo, A. (2009). Intuitions of 'infinite numbers': Infinite magnitude vs. infinite representation. The Montana Mathematics Enthusiast, 6(3), 305-330.

Mısral, M. (2009). Kesrin farklı anlamlarına göre yapılan öğretimin İlköğretim 6. Sınıf öğrencilerinin kesirlerde toplama çlkarma ve çarpma işlemlerinde kavramsal ve işlemsel bilgi düzeylerine etkisi [the effect of the education which is done by the 
different subconstructs of fractions on the conceptual and operational knowledge levels of primary school 6th grade students about adding subtraction and multiplication in fraction]. (Masters' Thesis). Retrieved from Turkish Council of Higher Education Thesis Database (Thesis Number: 237470).

Montague, M. (2006). Math problem solving for middle school students with disabilities. Washington, DC: The Access Center: Improving Outcomes for all Students K-8. Retrieved on November 11, 2021, from http://www.k8accesscenter.org

Muzheve, M. T. (2014). Pre-service teachers' conceptions of representations of equivalent fractions and of fraction units. In Matney, G. T. and Che, S. M. (Eds.) (pp. 57-63). Proceedings of the 41st Annual Meeting of the Research Council on Mathematics Learning. San Antonio, TX.

$\mathrm{Ni}, \mathrm{Y}$. (2001). Semantic domains of rational numbers and the acquisition of fraction equivalence. Contemporary Educational Psychology, 26, 400-417.

Niemi, D. (1996). Instructional influence on content area explanations and represenational knowledge: Evidence for the construct validity of measures of principled understanding. CSE Technical Report 403. National Center for Research on Evaluation, Standards, and Student Testing, Los Angeles, CA: University of California.

Nistal, A. A., Van Dooren, W., Clarebout, G., Elen, J., \& Verschaffel, L. (2009). Conceptualising, investigating and stimulating representational flexibility in mathematical problem solving and learning: a critical review. ZDM, 41(5), 627-636.

Olkun S., \& Toluk Uçar Z. (2004). IIlköğretimde etkinlik temelli matematik öğretimi. Ankara: Anı Yayıncılık.

Park, J., Güçler, B., \& McCrory, R. (2013). Teaching prospective teachers about fractions: Historical and pedagogical perspectives, Educational Studies in Mathematics, 82(3), 455-479.

Pesen, C. (2003). Eğitim fakülteleri ve sinıf öğretmenleri için matematik öğretimi. Ankara: Nobel Yayın Dağıtım

Pesen, C. (2008). Kesirlerin sayi doğrusu üzerindeki gösteriminde öğrencilerin öğrenme güçlükleri ve kavram yanilgilari [students' learning difficulties and misconceptions in pointing the fractions on the number line]. Inonu University Journal of the Faculty of Education, 9(15), 157-168.

Piaget, J. (1983). Piaget's Theory. In P. Mussen (Ed.) Handbook of child psychology. Wiley.

Piaget, J. (1987). Possibility and necessity. Vol. II: The role of necessity in cognitive development. Minneapolis: University of Minnesota Press.

Piaget, J., Inhelder, B., \& Szeminska, A. (1960). The child's conception of geometry. (E.A. Lunzer, Trans.) New York: Basic Books. (Original work published 1948).

Putra, Z. H. (2018). A praxeological analysis of pre-service elementary teachers' knowledge of rational numbers. Recherches En Didactique Des Mathematiques, 38(3), 315-364. 
Putra, Z. H. (2019). Praxeological change and the density of rational numbers: The case of pre-service teachers in Denmark and Indonesia. Eurasia Journal of Mathematics, Science and Technology Education, 15(5), em1711.

Sidney, P. G., Thompson, C. A., \& Rivera, F. D. (2019). Number lines, but not area models, support children's accuracy and conceptual models of fraction division. Contemporary Educational Psychology, 58, 288-298.

Siebert, D. \& Gaskin, N. (2006). Creating, naming, and justifying fractions. Teaching Children Mathematics, 12(8), 394-400.

Sirotic, N., \& Zazkis, R. (2007). Irrational numbers on the number line - where are they? International Journal of Mathematical Education in Science and Technology, 38(4), 477-488. https://doi.org/10.1080/00207390601151828

Streefland, L. (1991). Fractions in realistic mathematics education: A paradigm of developmental research, The Netherlands, Kluwer Academic Publishers.

Toluk, Z. (2002). İlkokul öğrencilerinin bölme işlemi ve rasyonel sayıları ilişkilendirme süreçleri [Division process and rational numbers association processes of primary school students]. Boğaziçi Üniversitesi Eğitim Dergisi, 19(2), 81-101.

Toluk-Uçar, Z. (2009). Developing pre-service teachers understanding of fractions through problem posing. Teaching and Teacher Education, 25(1), 166-175.

Wong, M., Evans, D. \& Anderson, J. (2006). Developing a diagnostic assessment instrument for identifying students' understanding of fraction equivalence. The University of Sydney. ACSPRI Conference.( December) Sydney, Australia.

Wong, M. \& Evans, D. (2011). Assessing students' understanding of fraction equivalence. In J. Way \& J. Bobis (Eds.), Fractions: Teaching for Understanding (pp. 81-90). Adelaide: The Australian Association of Mathematics Teachers Inc.

Yazgan, Y. (2007). 10-11 yaş grubundaki öğrencilerin kesirleri kavramalari üzerine deneysel bir çalişma [An experimental study on fraction understanding of children at the age of 10 and 11]. (Doctoral Dissertation). Retrieved from Turkish Council of Higher Education Thesis Database (Thesis Number: 220989). 


\section{Appendix A: An Example Item of RTF}

Circle the items below that show the same amount as $\frac{2}{4}$ :
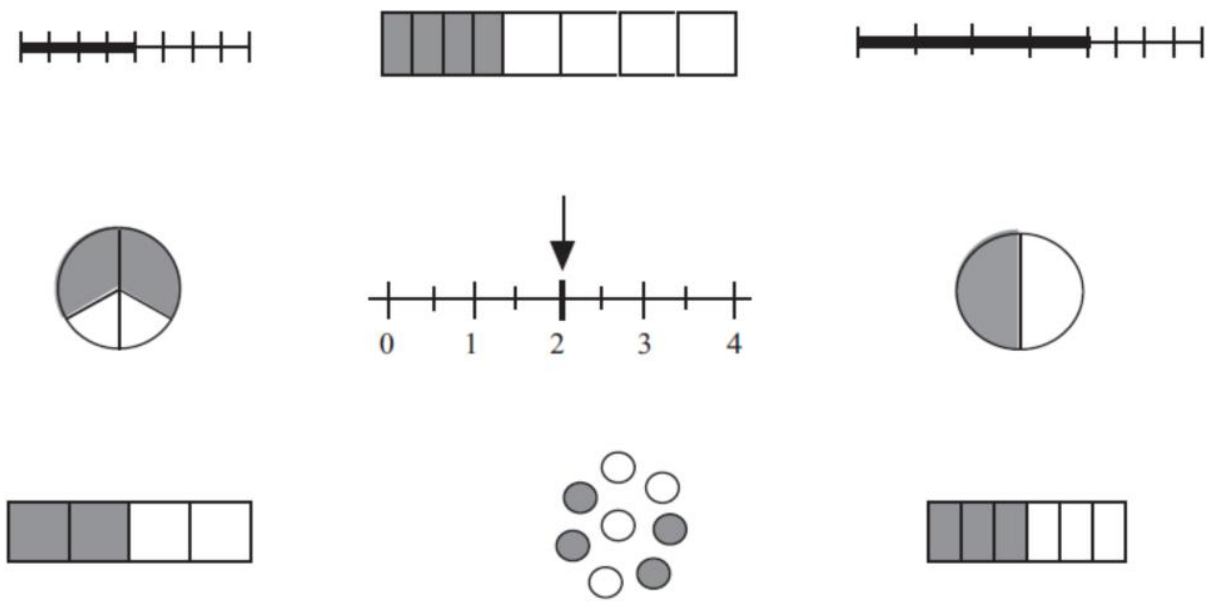

10
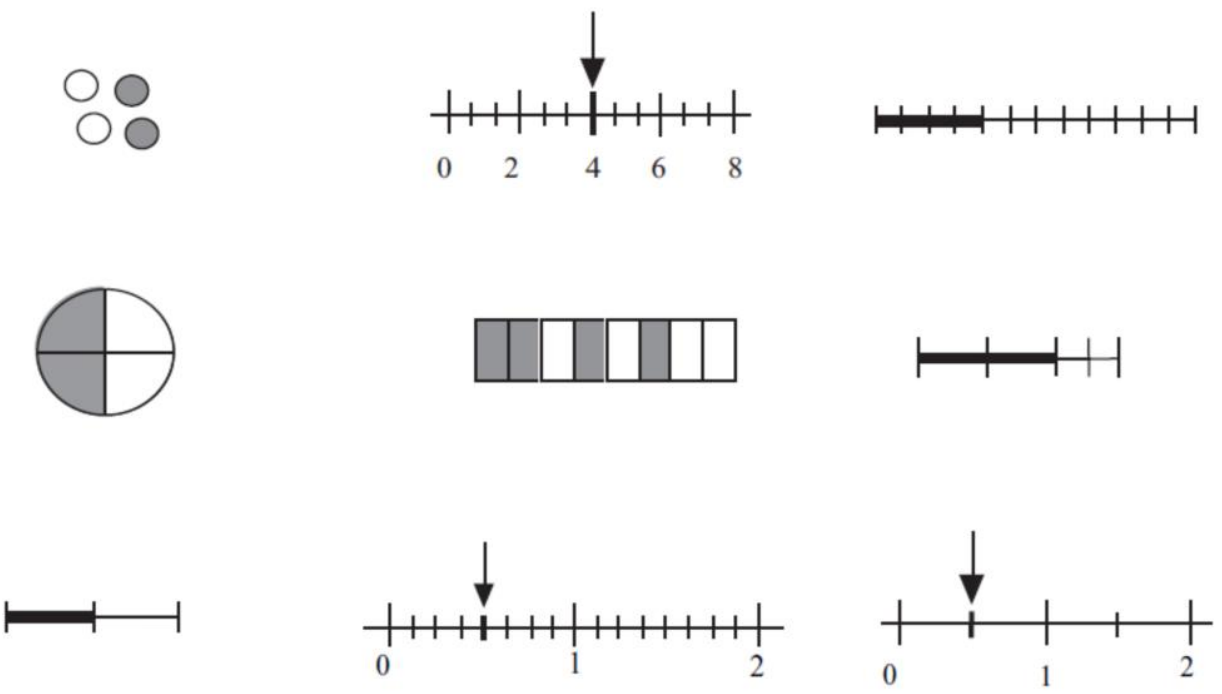
Ethics committee approval for this study was obtained from the Ethics Committee of Rectorate, Sakarya University, dated 15.09.2021 and numbered 34.

\section{Statement of Contribution of Researchers to the Article:}

1st author contribution rate: $50 \%$

2nd author contribution rate: $50 \%$

Conflict of Interest Statement:

There is no conflict of interest.

Statement of Financial Support or Acknowledgment:

No financial support was received from any institution for this study. 